\title{
PENGARUH LIKUIDITAS, SOLVABILITAS, AKTIVITAS DAN PROFITABILITAS TERHADAP NILAI PERUSAHAAN PADA PT ASTRA INTERNASIONAL, TBK YANG TERDAFTAR DI BURSA EFEK INDONESIA
}

\author{
Oleh: \\ Ruth Tridianty Sianipar \\ S1 Akuntansi \\ Parman Tarigan, Jubi, Ady Inrawan
}

Abstraksi

Tujuan dari penelitian ini adalah untuk mengetahui gambaran rasio likuiditas, solvabilitas, aktivitas, profitabilitas dan nilai perusahaan serta mengetahui pengaruh rasio likuiditas, solvabilitas, aktivitas dan profitabilitas terhadap nilai perusahaan baik secara simultan maupun parsial pada PT Astra Internasional, Tbk yang terdaftar di Bursa Efek Indonesia. Penelitian ini dilakukan dengan menggunakan metode analisis deskriptif kualitatif dan analisis deskriptif kuantitatif. Objek penelitian adalah PT Astra Internasional, Tbk yang terdaftar di Bursa Efek Indonesia. Pengumpulan data dilakukan dengan studi kepustakaan. Analisis data dilakukan dengan menggunakan bantuan software statistic SPSS 17.

Hasil analisis regresi linier berganda adalah $\mathrm{Y}=12,081-6,139 \mathrm{X}_{1}-5,917 \mathrm{X}_{2}+1,470 \mathrm{X}_{3}+33,177 \mathrm{X}_{4}$, artinya likuiditas dan solvabilitas berpengaruh negatif terhadap nilai perusahaan sedangkan aktivitas dan profitabilitas berpengaruh positif terhadap nilai perusahaan. Hasil analisis koefisien korelasi adalah sebesar 0,791 yang berarti bahwa terdapat hubungan yang kuat antara variabel bebas dengan variabel terikat. Koefisien determinasi adalah sebesar 0,626, yang berarti bahwa $62,6 \%$ variasi dari nilai perusahaan dijelaskan oleh likuiditas, solvabilitas, aktivitas dan profitabilitas. Hipotesis penelitian $\mathrm{H}_{0}$ diterima, artinya likuiditas, solvabilitas, aktivitas dan profitabilitas berpengaruh tidak signifikan terhadap nilai perusahaan baik secara simultan maupun parsial pada PT Astra Internasional, Tbk yang terdaftar di Bursa Efek Indonesia. Untuk itu, penting bagi perusahaan untuk tetap menjaga kondisi kesehatan perusahaan agar investor tetap berminat untuk menanamkan modalnya di perusahaan.

Kata Kunci: Likuiditas, Solvabilitas, Aktivitas, Profitabilitas dan Nilai Perusahaan

\section{Abstraction}

The aims of this research are to determine the description of liquidity, solvency, activity, profitability, and firm value and to determine the influence of liquidity, solvency, activity and profitability to firm value at PT Astra Internasional, Tbk listed at Indonesia Stock Exchange. This research was done using qualitative and quantitative descriptive analysis method. The object of this research is PT Astra Internasional, Tbk listed at Indonesia Stock Exchange. The data collecting was done by literature study. The data analysis method used is SPSS 17.0.

The result of multiple regression analysis is $Y=12,081-6,139 X_{1}-5,917 X_{2}+1,470 X_{3}+33,177 X_{4}$, indicate there is a negative relationship between liquidity and solvency with firm value, and a positive relationship between activity and profitability with firm value. The coefficient of correlation is 0,791, indicate there is a powerful relationship between independent variables with dependent variable. The coefficient of determination is 0,626, indicate the influence of liquidity, solvency, activity, and profitability. The hypothesis test result is $H_{0}$ accepted, indicate that liquidity, solvency, activity and profitability have no significantly influence to firm value at PT Astra Internasional, Tbk listed at Indonesia Stock Exchange. So, it is important to take the company in good condition persistently to keep the investor have an interest to invest in company.

Keyword: Liquidity, Solvency, Activity, Profitability and Firm Value

\section{A. PENDAhuluan}

1. Latar Belakang Masalah

Tujuan utama dari perusahaan adalah memaksimalkan nilai perusahaan dan kemakmuran pemegang saham. Nilai perusahaan adalah nilai pasar atas saham yang beredar. Adapun dalam penelitian ini, nilai perusahaan dihitung dengan menggunakan price to book value (PBV). Menurut Wibowo (2009:29), price to book value (PBV) mengukur seberapa besar pasar menghargai nilai buku saham suatu perusahaan.

Menurut Brigham dan Joel (2010:150), jika rasio likuiditas, manajemen aset, manajemen utang, dan profitabilitas semuanya terlihat baik dan jika kondisi ini berjalan terus menerus secara stabil maka rasio nilai pasar juga akan tinggi, harga saham kemungkinan tinggi sesuai dengan yang diperkirakan, dan manajemen telah melakukan pekerjaannya dengan baik sehingga sebaiknya mendapat imbalan. Jika sebaliknya, mungkin ada perubahan yang harus dilakukan. Berdasarkan pendapat ahli tersebut, dapat disimpulkan bahwa rasio likuiditas, manajemen aset yang biasa disebut aktivitas, manajemen utang yang biasa disebut solvabilitas dan profitabilitas merupakan faktorfaktor yang dapat mempengaruhi nilai perusahaan. 
Sementara menurut Horne dan John (2012:4), kesejahteraan para pemegang saham diwakili oleh harga pasar per lembar saham biasa perusahaan, yang merupakan cerminan dari keputusan investasi, pendanaan, dan manajemen aset perusahaan. Idenya adalah keberhasilan keputusan bisnis harus dinilai dari pengaruhnya terhadap harga saham. Berdasarkan pendapat ahli tersebut, dapat disimpulkan bahwa keputusan bisnis mempengaruhi nilai perusahaan yang tercermin dari harga saham.

PT Astra Internasional, Tbk yang tercatat di Bursa Efek Indonesia merupakan perusahaan yang bergerak di sektor aneka industri. Perusahaan ini dipilih untuk diteliti dengan mempertimbangkan bahwa perusahaan ini merupakan perusahaan yang rata-rata sahamnya direkomendasikan pada tahun 2013 namun hingga pada awal tahun 2015 mendapat perhatian karena mengalami pelemahan (wWw.vibiznews.com).

\section{Rumusan Masalah}

a. Bagaimana gambaran rasio likuiditas, solvabilitas, aktivitas, profitabilitas dan nilai perusahaan pada PT Astra Internasional, Tbk yang terdaftar di Bursa Efek Indonesia?

b. Bagaimana pengaruh rasio likuiditas, solvabilitas, aktivitas dan profitabilitas terhadap nilai perusahaan baik secara simultan maupun parsial pada PT Astra Internasional, Tbk yang terdaftar di Bursa Efek Indonesia?

\section{Tujuan Penelitian}

a. Untuk mengetahui gambaran rasio likuiditas, solvabilitas, aktivitas, profitabilitas dan nilai perusahaan pada PT Astra Internasional, Tbk yang terdaftar di Bursa Efek Indonesia.

b. Untuk mengetahui pengaruh rasio likuiditas, solvabilitas, aktivitas dan profitabilitas terhadap nilai perusahaan baik secara simultan maupun parsial pada PT Astra Internasional, Tbk yang terdaftar di Bursa Efek Indonesia.

\section{Metode Penelitian}

Dalam penelitian ini, penulis mengambil objek penelitian pada PT Astra Internasional, Tbk, Jln. Gaya Motor Raya No. 8 Sunter II Jakarta 14330 dengan cara mengakses data melalui situs www.idx.co.id.

Adapun Desain penelitian yang digunakan dalam penulisan penelitian ini adalah Penelitian Kepustakaan (Library Research). Teknik pengumpulan data yang dilakukan penulis dalam penelitian ini adalah dokumentasi. Adapun jenis data yang digunakan dalam penelitian ini adalah jenis data kualitatif dan data kuantitatif. Hasil data yang diperoleh akan dianalisis secara deskriptif baik bersifat kualitatif dan kuantitatif.

\section{B. LANDASAN TEORI}

\section{Analisis Laporan Keuangan}

Menurut Horne dan John (2012:154), analisis laporan keuangan merupakan seni untuk mengubah data dari laporan keuangan ke informasi yang berguna bagi pengambilan keputusan. Menurut
Kasmir (2010:96), jenis-jenis teknik analisis laporan keuangan yang dapat dilakukan adalah sebagai berikut:

a. Analisis Perbandingan antara Laporan Keuangan, merupakan analisis yang dilakukan dengan membandingkan laporan keuangan lebih dari satu periode.

b. Analisis Trend, dilakukan dari periode ke periode sehingga akan terlihat apakah perusahaan mengalami perubahan yaitu naik, turun atau tetap, serta perubahan besar perubahan tersebut yang dihitung dalam persentase.

c. Analisis Persentase Per Komponen, merupakan analisis yang dilakukan untuk membandingkan antara komponen yang ada dalam suatu laporan keuangan, baik yang ada di neraca maupun laporan laba rugi.

d. Analisis Sumber dan Penggunaan Dana, merupakan analisis yang dilakukan untuk mengetahui sumber-sumber dana perusahaan dan penggunaan dana dalam suatu periode.

e. Analisis Sumber dan Penggunaan Kas, merupakan analisis yang digunakan untuk mengetahui sumber-sumber kas perusahaan dan penggunaan uang kas dalam suatu periode.

f. Analisis Rasio, merupakan analisis yang digunakan untuk mengetahui hubungan pos-pos yang ada dalam satu laporan keuangan atau pospos antara laporan keuangan neraca dan laporan laba rugi.

g. Analisis Laba Kotor, merupakan analisis yang digunakan untuk mengetahui jumlah laba kotor dari periode kesatu periode.

h. Analisis Titik Pulang Pokok disebut juga Analisis Titik Impas atau Break Even Point, untuk mengetahui pada konsisi berapa penjualan atau produk dilakukan dan perusahaan tidak mengalami kerugian.

Menurut Sudana (2011:20), salah satu cara memperoleh informasi yang bermanfaat dari laporan keuangan perusahaan adalah dengan melakukan analisis rasio keuangan. Rasio keuangan didesain untuk memperlihatkan hubungan antarakun pada laporan keuangan (neraca dan laporan laba rugi). Menurut Sudana (2011:20), ada 5 jenis rasio keuangan, yaitu sebagai berikut:

a. Leverage Ratio

Rasio ini mengukur berapa besar penggunaan utang dalam pembelanjaan perusahaan.

b. Liquidity Ratio

Rasio ini mengukur kemampuan perusahaan untuk memenuhi kewajiban keuangan jangka pendek.

c. Activity Ratio

Rasio ini mengukur efektivitas dan efisiensi perusahaan dalam mengelola aktiva yang dimiliki perusahaan.

d. Profitability Ratio

Rasio ini mengukur kemampuan perusahaan untuk menghasilkan laba dengan menggunakan sumber-sumber yang dimiliki perusahaan, seperti aktiva, modal, atau penjualan perusahaan.

e. Market Value Ratio 
Rasio ini terkait dengan penilaian kinerja saham perusahaan yang telah diperdagangkan di pasar modal (go public).

\section{Rasio Likuiditas}

Menurut Brigham dan Joel (2010:134), rasio likuiditas adalah rasio yang menunjukkan hubungan antara kas dan aset lancar perusahaan lainnya dengan kewajiban lancarnya. Dua rasio likuiditas yang umum digunakan adalah rasio lancar (current ratio) dan rasio cepat (quick ratio). Rasio lancar menunjukkan sampai sejauh apa kewajiban lancar ditutupi oleh aset yang diharapkan akan dikonversi menjadi kas dalam waktu dekat.

$$
\text { Rasio Lancar }=\frac{\text { Aset Lancar }}{\text { Liabilitas Jangka Pendek }}
$$

Sementara menurut Horne dan John (2012:168), rasio cepat menunjukkan kemampuan perusahaan untuk memenuhi liabilitas jangka pendek dengan aset yang paling likuid.

$$
\text { Rasio Cepat }=\frac{\text { Aset Lancar- Persediaan }}{\text { Liabilitas Jangka Pendek }}
$$

Dalam penelitian ini, rasio likuiditas diukur dengan menggunakan rasio lancar (current ratio).

\section{Rasio Solvabilitas}

Menurut Kasmir (2010:112), rasio solvabilitas atau leverage ratio merupakan rasio yang digunakan untuk mengukur sejauh mana aktiva perusahaan dibiayai dengan utang. Ada dua cara yang umum digunakan untuk mengukur rasio solvabilitas yaitu: Rasio Utang terhadap Ekuitas (Debt to Equity Ratio) dan Rasio Utang terhadap Total Aset (Debt to Asset Ratio).

Menurut Kasmir (2010:112), debt to equity ratio merupakan rasio yang digunakan untuk menilai utang dengan ekuitas. Rasio ini berguna untuk mengetahui jumlah dana yang disediakan peminjam dengan pemilik perusahaan.

Rasio Utang terhadap Ekuitas $=\frac{\text { Total Utang }}{\text { Ekuitas Pemegang Saham }}$

Selanjutnya, masih menurut Kasmir (2010:112), debt to asset ratio merupakan rasio utang yang digunakan untuk mengukur seberapa besar aktiva perusahaan dibiayai oleh utang atau seberapa besar utang perusahaan berpengaruh terhadap pengelolaan aktiva.

Rasio Utang terhadap Total Aset $=\frac{\text { Total Utang }}{\text { Total Aset }}$

Dalam penelitian ini, rasio solvabilitas diukur dengan menggunakan rasio utang terhadap ekuitas atau debt to equity ratio (DER).

\section{Rasio Aktivitas}

Menurut Astuti (2004:32), rasio aktivitas ini menunjukkan seberapa cepat aktiva lancar dapat dikonversi ke dalam kas. Adapun cara yang umum digunakan untuk mengukur rasio aktivitas adalah perputaran persediaan (inventory turnover), perputaran aktiva tetap (fixed asset turnover), dan perputaran total aktiva (total asset turnover)
Dalam penelitian ini, rasio aktivitas diukur dengan menggunakan perputaran total aktiva/aset atau total asset turnover.

Rasio Perputaran Total Aktiva $=\frac{\text { Penjualan }}{\text { Total Aktiva }}$

\section{Rasio Profitabilitas}

Menurut Brigham dan Joel (2010:146), rasio profitabilitas adalah sekelompok rasio yang menunjukkan kombinasi dari pengaruh likuiditas, manajemen aset, dan utang pada hasil operasi. Adapun cara yang umum digunakan untuk mengukur rasio profitabilitas adalah pengembalian atas total aset (return on asset) dan pengembalian atas ekuitas (return on equity).

Dalam penelitian ini, rasio profitabilitas diukur dengan menggunakan return on asset. Return on asset merupakan rasio yang menunjukkan hasil atas sejumlah aktiva yang digunakan dalam perusahaan. Selanjutnya menurut Brigham dan Joel (2010:148), rasio laba bersih terhadap total aset mengukur pengembalian atas total aset setelah bunga dan pajak.

Pengembalian atas Total Aset $=\frac{\text { Laba Bersih }}{\text { Total Aset }}$

\section{Nilai Perusahaan}

Menurut Keown. et. al. (2004:470), yang dimaksud dengan nilai perusahaan adalah nilai pasar atas surat berharga hutang dan ekuiti perusahaan yang beredar. Dalam penelitian ini nilai perusahaan diukur dengan menggunakan price to book value (PBV) atau disebut juga market to book value ratio. Menurut Wibowo (2009:29), price to book value (PBV) mengukur seberapa besar pasar menghargai nilai buku saham suatu perusahaan.

Adapun cara untuk menghitung rasio nilai pasar/ nilai buku atau biasa disebut price to book value (PBV) maupun market to book value ratio $(\mathrm{M} / \mathrm{B})$ adalah:

$$
\begin{gathered}
\text { Rasio nilai pasar/nilai buku }=\frac{\text { Harga Pasar per Saham }}{\text { Nilai Buku per Saham }} \\
\text { Nilai Buku per Saham }=\frac{\text { Ekuitas Biasa }}{\text { Jumlah Saham Beredar }}
\end{gathered}
$$

\section{Pengaruh Likuiditas, Solvabilitas,} Aktivitas dan Profitabilitas Terhadap Nilai Perusahaan

Menurut Brigham dan Joel (2010:150), jika rasio likuiditas, manajemen aset, manajemen utang, dan profitabilitas semuanya terlihat baik dan jika kondisi ini berjalan terus menerus secara stabil maka rasio nilai pasar juga akan tinggi, harga saham kemungkinan tinggi sesuai dengan yang diperkirakan, dan manajemen telah melakukan pekerjaannya dengan baik sehingga sebaiknya mendapat imbalan. Jika sebaliknya, mungkin ada perubahan yang harus dilakukan.

Adapun dalam penelitian ini rasio likuiditas diukur dengan menggunakan rasio lancar atau current ratio (CR). Menurut Brigham dan Joel (2010:135), jika suatu perusahaan mengalami kesulitan keuangan, perusahaan mulai lambat 
membayar tagihan (utang usaha), pinjaman bank, dan kewajiban lainnya yang akan meningkatkan kewajiban lancar. Ketika rasio lancar menurun, hal ini menunjukkan adanya masalah pada perusahaan, sehingga dapat diartikan bahwa rasio likuiditas perusahaan dalam keadaan yang tidak baik dan kemungkinan akan menurunkan nilai perusahaan.

$$
\text { Menurut Kasmir (2010:112), rasio }
$$
solvabilitas atau leverage ratio merupakan rasio yang digunakan untuk mengukur sejauh mana aktiva perusahaan dibiayai dengan utang. Dalam penelitian ini, solvabilitas diukur dengan menggunakan debt to equity ratio (DER). Menurut Sudana (2011:153), investor yang rasional akan memandang bahwa peningkatan nilai perusahaan berasal dari penggunaan utang yang tinggi. Dengan demikian investor mungkin akan menawarkan harga saham yang lebih tinggi setelah perusahaan menerbitkan utang untuk membeli kembali saham yang beredar.

Menurut Kasmir (2010:113), rasio aktivitas digunakan untuk menilai kemampuan perusahaan dalam melaksanakan aktivitas sehari-hari. Dalam penelitian ini, aktivitas diukur dengan menggunakan total asset turnover (TATO). Semakin tinggi rasio aktivitas dapat berarti bahwa semakin tinggi jumlah penjualan yang diperoleh dari tiap rupiah aktiva. Hal ini berarti semakin tinggi rasio aktivitas, maka akan terlihat semakin baik dan kemungkinan akan meningkatkan nilai perusahaan yang tercermin melalui harga saham.

$$
\text { Menurut Kasmir (2010:115), rasio }
$$
profitabilitas merupakan rasio untuk menilai kemampuan perusahaan dalam mencari keuntungan. Dalam penelitian ini, profitabilitas diukur dengan menggunakan return on asset (ROA). Return on asset (ROA) dipilih karena menggambarkan pengembalian yang diterima atas keputusan investasi yang diambil perusahaan.

$$
\text { Menurut Astuti (2004:37), hasil }
$$
pengembalian total aktiva atau total investasi menunjukkan kinerja manajemen dalam menggunakan aktiva perusahaan untuk menghasilkan laba. Hasil pengembalian ini dapat dibandingkan dengan penggunaan alternatif dari dana tersebut. Sebagai salah satu ukuran kefektifannya, maka semakin tinggi hasil pengembalian, semakin efektiflah perusahaan. Hal ini akan mengakibatkan meningkatnya nilai perusahaan yang tercermin dari harga saham karena investor memandang hal tersebut menunjukkan kemampuan perusahaan untuk memberikan pengembalian yang tinggi.

\section{PEMBAHASAN}

\section{Analisa}

\section{a. Uji Asumsi Klasik}

Uji normalitas dengan pengujian One Sample Kolmogorov-Smirnov diperoleh nilai Asymp Sig. (2tailed) sebesar 0,710 yang berarti nilai tersebut di atas nilai signifikan $0,710>0,05$. Dengan demikian dapat dikatakan bahwa variabel residual berdistribusi normal. Uji multikolinieritas yang digunakan dalam penelitian ini adalah uji multikolinieritas dengan
TOL (Tolerance) dan Variance Inflation Factor (VIF), dengan hasil pengujian sebagai berikut: nilai VIF (Variance Infloating Factor) variabel CR sebesar 4,058, variabel DER sebesar 5,458, variabel TATO sebesar 2,671 dan variabel ROA sebesar 4,050. Dengan melihat VIF (Variance Infloating Factor) variabel CR, DER, TATO dan ROA seluruhnya lebih kecil dari 10, maka pada model regresi yang terbentuk tidak terjadi gejala multikolinieritas.

Dari grafik scatterplot terlihat bahwa plot menyebar secara acak di atas maupun di bawah angka nol pada sumbu Regression Studentized Residual. Oleh karena itu, maka berdasarkan uji heteroskedastisitas menggunakan metode analisis grafik, pada model regresi yang terbentuk dinyatakan tidak terjadi gejala heteroskedastisitas. Nilai DurbinWatson dalam penelitian ini adalah sebesar 2,141. Berdasarkan tabel Durbin-Watson diketahui bahwa dengan $\mathrm{n}=9, \mathrm{k}=4$, maka akan diperoleh nilai $\mathrm{dL}=0,296$ dan $\mathrm{dU}=2,586$. Maka nilai DurbinWatson berada pada $\mathrm{dL}<\mathrm{DW}<\mathrm{dU}$ atau dapat dijelaskan bahwa $0,296<2,141<2,586$. Dengan demikian dapat dikatakan bahwa hasil pengujian autokorelasi adalah tanpa kesimpulan.

\section{b. Deskriptif Kualitatif}

Analisis deskriptif dalam penelitian ini bertujuan untuk mendapatkan gambaran atau deskripsi mengenai likuiditas, solvabilitas, aktivitas, profitabilitas dan nilai perusahaan pada PT Astra Internasional, Tbk yang terdaftar di Bursa Efek Indonesia.

1) Gambaran Likuiditas Pada PT Astra Internasional, Tbk yang terdaftar di Bursa Efek Indonesia

Berdasarkan hasil analisis diperoleh hasil bahwa likuiditas perusahaan mengalami fluktuasi setiap tahunnya. Current ratio (CR) minimum perusahaan periode 2006-2014 adalah sebesar 0,78 berada pada tahun 2006. Hal ini disebabkan pada tahun 2006 aset lancar perusahaan memiliki jumlah yang jauh lebih rendah dari pada kewajiban lancar. Current ratio (CR) maksimum perusahaan periode 2006-2014 adalah sebesar 1,40 pada tahun 2012. Pada saat perusahaan mencapai current ratio (CR) maksimum jumlah aset lancar perusahaan jauh lebih besar dari pada kewajiban lancarnya.

2) Gambaran Solvabilitas Pada PT Astra Internasional, Tbk yang terdaftar di Bursa

\section{Efek Indonesia}

Berdasarkan hasil analisis diperoleh hasil bahwa debt to equity ratio (DER) minimum perusahaan periode 2006-2014 adalah sebesar 0,96 berada pada tahun 2104. Hal ini disebabkan total kewajiban perusahaan memiliki jumlah yang lebih kecil dibanding total ekuitas perusahaan. Sedangkan debt to equity ratio (DER) maksimum perusahaan periode 2006-2014 adalah sebesar 1,41 berada pada tahun 2006. Pada saat debt to equity ratio (DER) perusahaan mencapai tingkat 
maksimum, hal ini disebabkan total kewajiban perusahaan memiliki jumlah lebih besar dibanding dengan total ekuitas perusahaan.

\section{3) Gambaran Aktivitas Pada PT Astra Internasional, Tbk yang terdaftar di Bursa Efek Indonesia}

Berdasarkan hasil analisis diperoleh hasil bahwa total asset turnover (TATO) minimum perusahaan adalah sebesar 0,85 berada pada tahun 2014, sementara total asset turnover (TATO) maksimum perusahaan adalah sebesar 1,20 berada pada tahun 2008. Pada saat total asset turnover (TATO) perusahaan mencapai tingkat minimum disebabkan perkembangan jumlah penjualan jauh lebih rendah daripada jumlah peningkatan total aset perusahaan. Sementara pada saat total asset turnover (TATO) perusahaan mencapai tingkat maksimum disebabkan peningkatan jumlah penjualan lebih tinggi dari pada jumlah aset perusahaan.

\section{4) Gambaran Profitabilitas Pada PT Astra Internasional, Tbk yang terdaftar di Bursa Efek Indonesia}

Berdasarkan hasil analisis diperoleh hasil bahwa profitabilitas perusahaan mengalami fluktuasi setiap tahunnya. Adapun return on asset (ROA) minimum perusahaan yang ditunjukkan pada Tabel 20 adalah sebesar 0,06 berada pada tahun 2006 sementara return on asset (ROA) maksimum perusahaan adalah sebesar 0,14 berada pada tahun 2011. Sedangkan rata-rata return on asset (ROA) adalah sebesar 0,11.

\section{5) Gambaran Nilai Perusahaan Pada PT Astra Internasional, Tbk yang terdaftar di Bursa Efek Indonesia}

Berdasarkan hasil analisis, terlihat bahwa nilai perusahaan mengalami fluktuasi setiap tahunnya. Harga saham perusahaan di pasar dinilai lebih (over value) dari nilai perusahaan itu sendiri. Namun nilai perusahaan mulai tahun 2011 sampai 2014 terus mengalami penurunan. Hal ini disebabkan aktivitas dan profitabilitas perusahaan pada tahun 2011 sampai tahun 2014 terus mengalami penurunan, sehingga perusahaan tidak dipandang baik oleh investor.

\section{c. Deskriptif Kuantitatif}

1) Analisis Regresi Linier Berganda

Berdasarkan hasil analisa dengan program SPSS, maka model regresi linear berganda yaitu sebagai berikut : $Y=\mathbf{1 2 , 0 8 1}-\mathbf{6 , 1 3 9} \mathrm{X}_{\mathbf{1}}-\mathbf{5 , 9 1 7} \mathrm{X}_{\mathbf{2}}$ $+1,470 \mathrm{X}_{3}+33,177 \mathrm{X}_{4}$

Berdasarkan hasil persamaan regresi di atas maka dapat disimpulkan bahwa likuiditas dan solvabilitas berpengaruh negatif terhadap nilai perusahaan, sementara aktivitas dan profitabilitas berpengaruh positif terhadap nilai perusahaan pada PT Astra Internasional, Tbk periode 2006-2014.

\section{2) Analisa Korelasi dan Determinasi}

Berdasarkan hasil pengolahan data SPSS diperoleh nilai koefisien korelasi adalah sebesar 0,791 yang berarti bahwa terdapat korelasi atau hubungan yang kuat antara variabel PBV dengan variabel independennya (CR, DER, TATO dan ROA). Sementara koefisien determinasi ( $R$ Square) adalah 0,626, berarti 62,6\% variasi dari PBV dijelaskan oleh variasi dari keempat variabel independen (CR, DER, TATO dan ROA), sedangkan sisanya dijelaskan oleh variasi atau faktor lainnya yang tidak dimasukkan dalam model regresi.

\section{3) Uji Hipotesis (uji F dan uji t)}

Uji F menunjukkan apakah semua variabel independen yang dimasukkan dalam model regresi mempunyai pengaruh secara bersama-sama terhadap variabel dependen. Uji ini dilakukan dengan membandingkan signifikansi $F$ dengan ketentuan sebagai berikut:

a) Jika nilai $\operatorname{Pr}$ (Sig.) $\geq \alpha(0,05)$ maka $\mathrm{H}_{0}$ diterima

b) Jika nilai $\operatorname{Pr}$ (Sig.) $<\alpha(0,05)$ maka $\mathrm{H}_{0}$ ditolak Adapun uji hipotesis adalah sebagai berikut:

a) $\mathrm{H}_{0}=0$, artinya likuiditas, solvabilitas, aktivitas dan profitabilitas berpengaruh tidak signifikan terhadap nilai perusahaan pada PT Astra Internasional, Tbk.

b) $\mathrm{Ha} \neq 0$, artinya likuiditas, solvabilitas, aktivitas dan profitabilitas berpengaruh signifikan terhadap nilai perusahaan pada PT Astra Internasional, Tbk.

Nilai $F$ hitung yang diperoleh tersebut akan dibandingkan dengan nilai $\mathrm{F}$ tabel. Adapun nilai $\mathrm{F}$ tabel dengan derajat bebas: df: $\alpha,(\mathrm{k}-1)$, (n-k) atau 0,05, (5-1), (9-5) adalah sebesar 6,388 . Berdasarkan hasil pengolahan data diperoleh F hitung sebesar 1,671 dan nilai ini lebih kecil dari $\mathrm{F}$ tabel sebesar 6,388 atau dapat dikatakan $1,671<6,388$. Sementara nilai probabilitas $(0,316)$ lebih besar daripada nilai $\alpha(0,05)$ atau dapat dikatakan 0,316>0,05 maka $\mathrm{H}_{0}$ diterima. Hal ini berarti secara simultan likuiditas, solvabilitas, aktivitas dan profitabilitas berpengaruh tidak signifikan terhadap nilai perusahaan pada PT Astra Internasional, Tbk periode 2006-2014.

Uji t dilakukan untuk menguji signifikan tidaknya pengaruh antara variabel independen terhadap variabel dependen dengan asumsi bahwa variabel lain dianggap konstan. Untuk menguji signifikansi koefisien persamaan regresi dirumuskan sebagai berikut:

a) Jika nilai $\operatorname{Pr}\left(\mathrm{Sig}\right.$.) $\geq \alpha(0,05)$ maka $\mathrm{H}_{0}$ diterima b) Jika nilai $\operatorname{Pr}($ Sig. $)<\alpha(0,05)$ maka $\mathrm{H}_{0}$ ditolak Adapun uji hipotesis adalah sebagai berikut:

a) $\mathrm{H}_{0}=0$, artinya likuiditas, solvabilitas, aktivitas dan profitabilitas berpengaruh tidak signifikan terhadap nilai perusahaan pada PT Astra Internasional, Tbk

b) $\mathrm{Ha} \neq 0$, artinya likuiditas, solvabilitas, aktivitas dan profitabilitas berpengaruh signifikan terhadap nilai perusahaan pada PT Astra Internasional, Tbk.

Dari hasil pengolahan data dengan uji $t$ dapat diketahui pengaruh masing-masing variabel 
independen terhadap variabel dependen sebagai berikut:

a) Current Ratio (CR) mempunyai nilai t hitung sebesar -2,216 lebih besar dari t tabel sebesar 2,776 atau dapat dikatakan $-2,216>-2,776$. Sementara nilai probabilitas CR $(0,091)$ lebih besar daripada nilai $\alpha(0,05)$ atau dapat dikatakan $0,091>0,05$, maka $\mathrm{H}_{0}$ diterima atau dapat dikatakan secara parsial CR berpengaruh tidak signifikan terhadap PBV pada PT Astra Internasional, Tbk periode 2006-2014.

b) Debt to equity ratio (DER) mempunyai nilai t hitung sebesar -1,187 lebih besar dari t tabel sebesar -2,776 atau dapat dikatakan $-1,187>-$ 2,776. Sementara nilai probabilitas DER $(0,301)$ lebih besar daripada nilai $\alpha(0,05)$ atau dapat dikatakan 0,301 >0,05, maka $\mathrm{H}_{0}$ diterima atau dapat dikatakan secara parsial DER berpengaruh tidak signifikan terhadap PBV pada PT Astra Internasional, Tbk periode 2006-2014.

c) Total asset turnover (TATO) mempunyai nilai $\mathrm{t}$ hitung sebesar 0,343 lebih kecil dari t tabel sebesar 2,776 atau dapat dikatakan 0,343 < 2,776. Sementara nilai probabilitas TATO $(0,749)$ lebih besar daripada nilai $\alpha(0,05)$ atau dapat dikatakan $0,749>0,05$, maka $\mathrm{H}_{0}$ diterima atau dapat dikatakan secara parsial TATO berpengaruh tidak signifikan terhadap PBV pada PT Astra Internasional, Tbk periode 2006-2014.

d) Return on asset (ROA) mempunyai nilai $\mathrm{t}$ hitung 1,273 lebih kecil dari t tabel sebesar 2,776 atau dapat dikatakan $1,273<2,776$. Sementara nilai probabilitas ROA $(0,272)$ lebih besar daripada nilai $\alpha(0,05)$ atau dapat dikatakan 0,272 $>0,05$, maka $\mathrm{H}_{0}$ diterima atau dapat dikatakan secara parsial ROA berpengaruh tidak signifikan terhadap PBV pada PT Astra Internasional, Tbk periode 2006-2014.

Sehingga berdasarkan hasil analisis uji $\mathrm{F}$ dan uji t dapat disimpulkan bahwa likuiditas, solvabiltas, aktivitas dan profitabilitas berpengaruh tidak signifikan terhadap nilai perusahaan baik secara simultan maupun parsial pada PT Astra Internasional, Tbk periode 2006-2014.

\section{Evaluasi}

\section{a. Likuiditas pada PT Astra Internasional, Tbk} yang Terdaftar di Bursa Efek Indonesia

Dari hasil penelitian, menunjukkan kondisi likuiditas PT Astra Internasional, Tbk periode 20062014 yang diukur dengan menggunakan current ratio (CR) mengalami fluktuasi. Kondisi ini terlihat dimana current ratio (CR) minimum perusahaan adalah sebesar 0,78 dan current ratio (CR) maksimum perusahaan adalah sebesar 1,40 dengan rata-rata current ratio (CR) periode 2006-2014 adalah sebesar 1,22. Pada saat current ratio (CR) berada pada tingkat minimum disebabkan oleh jumlah aset lancar lebih kecil dibanding dengan jumlah kewajiban lancarnya. Hal ini menunjukkan bahwa perusahaan sedang mengalami kesulitan keuangan. Sementara pada saat current ratio (CR) berada pada tingkat maksimum disebabkan oleh jumlah aset lancar lebih besar dibanding jumlah kewajiban lancar. Namun hal ini tidak menjamin perusahaan mampu membayar utangnya ketika jatuh tempo, karena distribusi aset lancar berada pada piutang pembiayaan, piutang usaha dan persediaan yang kemungkinan sulit untuk ditagih atau dikonversi menjadi kas.

\section{b. Solvabilitas pada PT Astra Internasional, Tbk yang Terdaftar di Bursa Efek Indonesia}

Dari hasil penelitian, menunjukkan kondisi solvabilitas PT Astra Internasional, Tbk periode 2006-2014 yang diukur dengan menggunakan debt to equity ratio (DER) mengalami fluktuasi. Kondisi ini terlihat dimana debt to equity ratio (DER) minimum perusahaan adalah sebesar 0,96 dan debt to equity ratio (DER) maksimum perusahaan adalah sebesar 1,41 dengan rata-rata debt to equity ratio (DER) periode 2006-2014 adalah sebesar 1,10.

Adapun pada saat debt to equity ratio (DER) perusahaan berada pada tingkat minimum disebabkan jumlah kewajiban perusahaan lebih kecil dibanding dengan jumlah ekuitas perusahaan. Hal ini berarti perusahaan pada saat itu lebih banyak menggunakan dana pihak perusahaan. Pada saat debt to equity ratio (DER) perusahaan berada pada tingkat maksimum disebabkan jumlah kewajiban perusahaan lebih besar dibanding dengan jumlah ekuitas perusahaan.

\section{c. Aktivitas pada PT Astra Internasional, Tbk} yang Terdaftar di Bursa Efek Indonesia

Dari hasil penelitian, menunjukkan kondisi aktivitas PT Astra Internasional, Tbk periode 20062014 yang diukur dengan menggunakan total asset turnover (TATO) mengalami fluktuasi. Kondisi ini terlihat dimana total asset turnover (TATO) minimum perusahaan adalah sebesar 0,85 dan total asset turnover (TATO) maksimum perusahaan adalah sebesar 1,20 dengan rata-rata debt total asset turnover (TATO) periode 2006-2014 adalah sebesar 1,04 .

Pada saat total asset turnover (TATO) berada pada tingkat minimum disebabkan jumlah penjualan perusahaan lebih kecil dibanding dengan total aset perusahaan. Hal ini menunjukkan bahwa perusahaan belum menggunakan aset perusahaan dengan efisien. Pada saat total asset turnover (TATO) berada pada tingkat maksimum perusahaan mencapai tingkat aktivitas 1,20 disebabkan jumlah penjualan lebih besar dibanding aset yang dimiliki perusahaan. Hal ini menunjukkan bahwa dari tiap Rp 1 aset yang dimiliki perusahaan, perusahaan mampu memperoleh penjualan sebesar Rp 1,20.

d. Profitabilitas pada PT Astra Internasional,

Tbk yang Terdaftar di Bursa Efek Indonesia

Dari hasil penelitian, menunjukkan kondisi profitabilitas PT Astra Internasional, Tbk periode 2006-2014 yang diukur dengan menggunakan return on asset (ROA) mengalami fluktuasi. Kondisi ini terlihat dimana return on asset (ROA) minimum perusahaan adalah sebesar 0,06 dan return on asset (ROA) maksimum perusahaan adalah sebesar 0,14 
dengan rata-rata return on asset (ROA) periode 2006-2014 adalah sebesar 0,11.

Pada saat return on asset (ROA) berada pada tingkat minimum sebesar 0,06, hal ini menunjukkan bahwa kemampuan perusahaan dalam memberikan pengembalian atas seluruh aset yang digunakan adalah sebesar 6\%. Sementara pada tingkat maksimum sebesar 0,14 menunjukkan bahwa perusahaan mampu memberikan $14 \%$ pengembalian atas seluruh aset yang digunakan.

\section{e. Nilai Perusahaan pada PT Astra Internasional, Tbk yang Terdaftar di Bursa Efek Indonesia}

Dari hasil penelitian, menunjukkan kondisi profitabilitas PT Astra Internasional, Tbk periode 2006-2014 yang diukur dengan menggunakan price to book value (PBV) mengalami fluktuasi. Kondis ini terlihat dimana price to book value (PBV) minimum perusahaan adalah sebesar 1,29 dan price to book value (PBV) maksimum perusahaan adalah sebesar 4,48 dengan rata-rata price to book value (PBV) periode 2006-2014 adalah sebesar 3,19. Nilai rendah price to book value (PBV) ini disebabkan oleh turunnya harga saham akibat pandangan investor terhadap perusahaan kurang baik, begitu juga sebaliknya. Namun nilai rata-rata price to book value (PBV) perusahaan menunjukkan bahwa perusahaan selalu dinilai lebih tinggi dari dari nilai bukunya.

f. Pengaruh Likuiditas, Solvabilitas, Aktivitas dan Profitabilitas Terhadap Nilai Perusahaan pada PT Astra Internasional, Tbk yang Terdaftar di Bursa Efek Indonesia

Berdasarkan hasil analisis regresi linier berganda yang telah dilakukan, diketahui bahwa likuiditas memiliki pengaruh negatif terhadap nilai perusahaan. Hal ini dapat dilihat dari persamaan regresi yaitu: $Y=12,081-6,139 X_{1}-5,917 X_{2}$ $+\mathbf{1 , 4 7 0} X_{\mathbf{3}}+\mathbf{3 3 , 1 7 7} X_{4}$. Hasil analisis regresi linier berganda tersebut tidak sesuai dengan pendapat ahli di atas yang menyatakan bahwa bila likuiditas terlihat baik (meningkat), nilai perusahaan yang tercermin dari harga saham akan meningkat.

Berdasarkan hasil analisis regresi linier berganda yang telah dilakukan, diketahui bahwa solvabilitas memiliki pengaruh negatif terhadap nilai perusahaan. Hasil analisis regresi linier berganda tersebut sesuai dengan pendapat ahli yang menyatakan bahwa ketika penggunaan utang mampu memberikan pengembalian yang tinggi maka akan dipandang baik, sebaliknya jika penggunaan utang tidak mampu memberikan pengembalian yang tinggi maka akan dipandang tidak baik.

Berdasarkan hasil analisis regresi berganda yang telah dilakukan, diketahui bahwa aktivitas memiliki pengaruh positif terhadap nilai perusahaan. Hal ini sesuai dengan pendapat ahli yang menyatakan bahwa ketika aktivitas terlihat baik (meningkat), maka akan meningkatkan nilai perusahaan yang tercermin dari harga saham.
Berdasarkan hasil analisis regresi berganda yang telah dilakukan, diketahui bahwa profitabilitas memiliki pengaruh positif terhadap nilai perusahaan. Hasil analisis regresi linier berganda tersebut sesuai dengan pendapat ahli yang menyatakan bahwa ketika profitabilitas terlihat baik (meningkat), maka akan meningkatkan nilai perusahaan yang tercermin dari harga saham.

\section{KESIMPULAN DAN SARAN}

\section{Kesimpulan}

a. Rata-rata likuiditas yang diukur dengan menggunakan current ratio (CR) adalah sebesar 1,22. Rata-rata solvabilitas yang diukur dengan menggunakan debt to equity ratio (DER) adalah sebesar 1,10. Rata-rata aktivitas yang diukur dengan menggunakan total asset turnover (TATO) adalah 1,04. Rata-rata profitabilitas yang diukur dengan menggunakan return on asset (ROA) adalah 0,11. Rata-rata nilai perusahaan yang diukur dengan menggunakan price to book value (PBV) adalah 3,19.

b. Dari hasil analisis regresi linier berganda yang telah dilakukan, diperoleh persamaan regresi sebagai berikut: $Y=\mathbf{1 2 , 0 8 1}-\mathbf{6 , 1 3 9} \mathbf{X}_{\mathbf{1}}-\mathbf{5 , 9 1 7}$ $X_{2}+\mathbf{1 , 4 7 0} X_{3}+\mathbf{3 3 , 1 7 7} X_{4}$. Persamaan regresi tersebut menunjukkan bahwa likuiditas dan solvabilitas memiliki pengaruh negatif terhadap nilai perusahaan sedangkan aktivitas dan profitabilitas memiliki pengaruh positif terhadap nilai perusahaan

c. Berdasarkan pengujian koefisien korelasi dan determinasi diketahui bahwa nilai $\mathrm{R}$ adalah 0,791 yang berarti bahwa terdapat korelasi atau hubungan yang kuat antara variabel nilai perusahaan dengan variabel independennya (likuiditas, solvabilitas. aktivitas dan profitabilitas). Sementara koefisien determinasi ( $R$ Square) adalah 0,626, hal ini berarti $62,6 \%$ variasi dari nilai perusahaan dijelaskan oleh variasi dari keempat variabel independen (likuiditas, solvabilitas. aktivitas dan profitabilitas), sedangkan sisanya dijelaskan oleh variasi atau faktor lainnya yang tidak dimasukkan dalam model regresi (faktor dari luar perusahaan yang meliputi informasi teknis yang terdiri dari perkembangan kurs, keadaaan pasar, volume frekwensi transaksi, dan kekuatan pasar, serta informasi yang berhubungan dengan kondisi sosial, ekonomi dan politik).

d. Hasil uji $F$ diperoleh $F$ hitung sebesar 1,671 dan nilai ini lebih kecil dari $\mathrm{F}$ tabel sebesar 6,388 atau dapat dikatakan 1,671 < 6,388. Sementara nilai probabilitas $(0,316)$ lebih besar daripada nilai $\alpha(0,05)$ atau dapat dikatakan 0,316 $>0,05$ maka $\mathrm{H}_{0}$ diterima. Hal ini berarti secara simultan likuiditas, solvabilitas, aktivitas dan profitabilitas berpengaruh tidak signifikan terhadap nilai perusahaan pada PT Astra Internasional, Tbk periode 2006-2014.

e. Berdasarkan uji t diperoleh nilai t hitung untuk likuiditas sebesar -2,216 lebih besar dari t tabel sebesar -2,776 atau dapat dikatakan -2,216 > - 
2,776 dengan nilai probabilitas $(0,091)$ lebih besar daripada nilai $\alpha(0,05)$ atau dapat dikatakan $0,091>0,05$, nilai t hitung untuk solvabilitas sebesar -1,187 lebih besar dari t tabel sebesar 2,776 atau dapat dikatakan $-1,187>-2,776$ dengan nilai probabilitas $(0,301)$ lebih besar daripada nilai $\alpha(0,05)$ atau dapat dikatakan 0,301 $>0,05$, nilai $\mathrm{t}$ hitung untuk aktivitas sebesar 0,343 lebih kecil dari t tabel sebesar 2,776 atau dapat dikatakan $0,343<2,776$ dengan nilai probabilitas $(0,749)$ lebih besar daripada nilai $\alpha$ $(0,05)$ atau dapat dikatakan $0,749>0,05$, sedangkan nilai $\mathrm{t}$ hitung untuk profitabilitas sebesar 1,273 lebih kecil dari t tabel sebesar 2,776 atau dapat dikatakan 1,273 < 2,776. Sementara nilai probabilitas $(0,272)$ lebih besar daripada nilai $\alpha(0,05)$ atau dapat dikatakan 0,272 $>0,05$, maka $\mathrm{H}_{0}$ diterima atau dapat dikatakan secara parsial likuiditas, solvabilitas, aktivitas dan profitabilitas berpengaruh tidak signifikan terhadap nilai perusahaan pada PT Astra Internasional, Tbk periode 2006-2014.

\section{Saran}

a. Berdasarkan hasil penelitian, menyatakan bahwa likuiditas, solvabilitas, aktivitas dan profitabilitas perusahaan berpengaruh tidak signifikan terhadap nilai perusahaan baik secara simultan maupun parsial, namun penting bagi perusahaan untuk tetap menjaga kondisi kesehatan perusahaan agar investor tetap berminat untuk menanamkan modalnya diperusahaan.

b. Bagi investor dan calon investor sebaiknya terlebih dahulu menganalisis informasi fundamental perusahaan, informasi yang bersifat teknis dan yang berhubungan dengan kondisi sosial, ekonomi dan politik sehingga bisa lebih mengontrol saham sendiri dengan logis dan terukur.

c. Sehubungan dengan keterbatasan yang ada pada penulis, penelitian ini masih terdapat kelemahankelemahan dan belum dapat mengungkapkan seluruh variabel yang dapat mempengaruhi nilai pada perusahaan PT Astra Internasional, Tbk yang terdaftar di Bursa Efek Indonesia. Sebagai bahan masukan penelitian selanjutnya, perlu dilakukan penelitian analisis teknikal dan yang berhubungan dengan kondisi sosial, ekonomi dan politik untuk mengetahui pengaruhnya terhadap nilai perusahaan.

\section{E. DAFTAR PUSTAKA}

Astuti, Dewi. 2004. Manajemen Keuangan Perusahaan. Jakarta: Penerbit Ghalia Indonesia.

Brigham, Eugene F. dan Joel F. Houston. 2010. Dasar-dasar Manajemen Keuangan: Essensial of Financial Management, Edisi 11, Buku 1. Jakarta: Salemba Empat.

Horne, James C. Van and John M. Wachowicz, Jr. 2012. Prinsip-Prinsip Manajemen Keuangan, Edisi Ketiga Belas, Buku 1. Jakarta: Salemba Empat.
Kasmir. 2010. Pengantar Manajemen Keuangan, Edisi Pertama, Cetakan Pertama. Jakarta: Kencana.

Keown, et.al. 2004. Manajemen Keuangan: Prinsipprinsip dan Aplikasi, Edisi Kesembilan, Jilid 1. Jakarta: PT Indeks Kelompok Gramedia.

Sudana, I Made. 2011. Manajemen Keuangan Perusahaan Teori dan Praktik. Jakarta : Erlangga.

Wibowo, Sampoerno. 2009. Manajemen Keuangan, Bandung. 
